\title{
Effects of Organic Materials on Phosphorus Forms under Submerged Condition in the Soils of Lake Geriyo Irrigation Project, Adamawa State, Nigeria.
}

\author{
Solomon, R. I., A. M. Saddiq and B. H. Usman \\ Deparment Of Soil Science, Modibbo Adama University Of Technology, Yola
}

\begin{abstract}
Experiment was conducted at the landscape unit of Modibbo Adama University of Technology, Yola, to study the effects of organic materials on phosphorus forms under submerged condition in the soils of Geriyo Irrigation project. Soils were incubated with cowdung and poultry droppings at 5, 10 and 15 tons/ha for a period of 90 days. Soil samples were collected at 30, 60 and 90 after submergence and processed for analyses. Results showed that the soils were slightly acidic, low in total nitrogen, available phosphorus, effective cation exchange capacity (ECEC), and percent base saturation (PBS). Characterized organic materials showed higher $N, P$, and $K$ contents in poultry droppings while cowdung had higher moisture and organic carbon contents. Irrespective of the type of organic materials, total $P$, organic $P$, available $P$ and other forms of $P$ increased significantly $(p<0.05)$ with increasing levels of organic materials in both trials. In the first trial, total $P$ and organic $P$ increased at 60 days of submergence and declined afterwards while available $P$ progressively increased up to 90 days of submergence, saloid $P$ and aluminum bound $P$ progressively decreased up to 90 days of submergence while iron and calcium bound $P$ were highest at 60 days of submergence. In the second trial, total $P$ and organic $P$ progressively decreased with time while available $P$ decreased at 60 days of submergence, saloid, aluminum and iron bound $P$ were highest at 60 days of submergence. This implies that the use of poultry droppings in the soils of Geriyo irrigation project may ensure the supply of phosphorus to sustain rice production despite the seasonal flooding in the area with high risk of iron toxicity/ antagonism.
\end{abstract}

\section{Introduction}

Phosphorus (P) is an essential element classified as a macronutrient due to the relatively large amount required by plants. It is important for the transfer of chemically bound energy in various processes in the metabolism of plants, synthesis, breaking down and conversion of fat, proteins, carbohydrates and vitamins and hastens maturity. It is also an important component of biological membranes and supports root and shoot growth of crops (Fadly, 2005).

Soil Phosphorus exists in various forms; inorganic $\mathrm{P}(\mathrm{Pi})$ and organic $\mathrm{P}(\mathrm{Po})$. These $\mathrm{P}$ forms differ in their behavior and fate in soils (Turner et al., 2007). The Pi usually accounts for 35 to $70 \%$ of total $\mathrm{P}$ in soil (Harrison, 1987). Primary P minerals including apatites, strengite, and variscite are very stable, and the release of available $P$ from these minerals by weathering is generally too slow to meet the crop demand, though direct application of phosphate rocks (i.e. apatites) has proved relatively efficient for crop growth in acidic soils. In contrast, secondary $\mathrm{P}$ minerals including calcium $(\mathrm{Ca})$, iron $(\mathrm{Fe})$, and aluminum $(\mathrm{Al})$ phosphates vary in their dissolution rates, depending on size of mineral particles and soil $\mathrm{pH}$ (Pierzynski et al., 2005; Oelkers and Valsami-Jones, 2008). All the $\mathrm{P}$ forms exist in complex equilibrium with each other, representing from very stable, sparingly available, to plant-available $\mathrm{P}$ pools such as labile $\mathrm{P}$ and solution $\mathrm{P}$.

Low availability of phosphorus is a major constraint to agricultural productivity in highly weathered tropical soils (Sahrawat et al., 2001) such as the soils of Geriyo irrigation project. Such soils have a significant capacity to sorb large amounts of phosphorus, taking them out of the soil solution. This limits the availability of inorganic phosphorus for plants, whether it is present in the soil or added as fertilizer. Tropical soils also contain small amounts of total phosphorus, with a relatively large proportion of this present in organic forms. Organic amenndments constitute major phosphorus turnover especially in the tropical soils (Bar-Yosef, 2004).

Apart from the low phosphorus availability inherent in these soils, the problem of fixation /complexation by iron and aluminum especially of iron under flooded conditions further aggravate phosphorus availability for crop use. At the same time, ferric iron compounds have low solubility in the soil solution, and conditions that favour the formation of this compound decreases iron availability (Schulte, 2004) and its deficiency can be induced by excess of phosphorus (Hesse, 2002).

The use of organic amendments is increasing with the development of organic farming and there is an increased use even among conventional farmers to sustain production and environment (Schulte, 2004). Therefore, the search for appropriate organic amendments to ensure supply of phosphorus, reduce risk of iron toxicity/chelation and sustain production is not only imperative but necessary. 


\section{Location of the Study Area}

\section{Materials And Methods}

The study was conducted in Modibbo Adama University of Technology (MAUTECH), Yola, Soil Science Laboratory and Landscape unit. The soil samples were collected from Geriyo Irrigation Project which is located $2 \mathrm{~km}$ North of Jimeta metropolis, Yola North Local Government Area, Adamawa State, within the savannah ecological zone of Nigeria. The location lies between $12^{\circ} 21^{\prime}$ to $22^{\circ} 18^{\prime}$ E latitude and $9^{\circ} 16^{\prime}$ to $19^{\circ} 19^{\prime}$ $\mathrm{N}$. longitude with altitude range of $150-180 \mathrm{~m}$ above the mean sea level. It has a total irrigation area of about 350ha which is divided into three phases viz; phase I with developed irrigation area of 20 ha, phase II is divided into three with $2 \mathrm{~A}(35 \mathrm{ha}), 2 \mathrm{~B}(60 \mathrm{ha})$ and $2 \mathrm{C}(45 \mathrm{ha})$ making a total developed irrigation area of 140ha and phase III is also divided into two with $3 \mathrm{~A}(140 \mathrm{ha})$ and $3 \mathrm{~B}(50 \mathrm{ha})$ making a total developed irrigation area of 190ha. The experimental material (soil samples) were collected from phase II plots (2B and 2C) and phase III (3B) of the project which are rice plots and are located in the lower section of the irrigation system.

The annual rainfall of the study area ranged from $700-1000 \mathrm{~mm}$ and temperature ranged from $15.2-$ $39^{\circ} \mathrm{C}$. The temperature is high throughout the year with a mean monthly temperature of $26.7^{\circ} \mathrm{C}$ in the south and $27.8^{\circ} \mathrm{C}$ in the northern part of the State (Adebayo, 1999). The amount of sunshine hours ranged from 2500 in the south to 3000 hours in the extreme north (Adebayo, 1999). The relative humidity varies seasonally in the State. It is extremely low $(20-30 \%)$ between January and March and starts increasing as from April and reaches its peak (above $70 \%$ ) in August and September. Relative humidity then starts to decrease as from October following the cessation of rains (Adebayo, 1999).

\section{Experimental Materials}

Two organic materials; Cow dung and poultry (Broilers) droppings sourced from the University farm were used. Nine $\mathrm{kg}(9 \mathrm{~kg}$ ) of soil samples (at field moisture condition) was collected from Geriyo and weighed into perforated plastic pots of height $=23.5 \mathrm{~cm}$, diameter $=22.5 \mathrm{~cm}$. This was kept under submergence at MAUTECH land scape unit for a period of 90 days. The organic materials were air dried and ground using porcelain mortar and pestle, sieved through a $2-\mathrm{mm}$ sieve for laboratory analysis and incorporation into the experimental pots.

The $\mathrm{pH}$ of the organic materials was determined in 1:2 organic matters to water ratio (Kanwar and Chopra, 1959). The organic carbon content of the organic materials was determined using NYC - 12 muffle furnace as described by Kanwar and Chopra (1959). Nitrogen content of the organic materials was determined as described by Kanwar and Chopra (1959). The P and $\mathrm{K}$ in the organic materials were determined as described by Kanwar and Chopra (1959).

\section{Soil Sampling, Preparation and Analyses}

Soil samples were taken randomly across the experimental field (Geriyo) to a depth of $20 \mathrm{~cm}$ and bulked for laboratory analysis before the commencement of the research. The soil samples were air-dried, crushed using a porcelain mortar and pestle and then sieved through a $2-\mathrm{mm}$ mesh sieve. Sieved samples were stored in labeled polythene bags for laboratory analysis. Cow dung and poultry droppings were analyzed for $\mathrm{pH}$, organic carbon, total nitrogen, organic phosphorus and total potassium contents while soil texture, bulk density, particle density, moisture content, porosity and color were determined as described by Jaiswal (2003).

The soil $\mathrm{pH}$ was measured in a 1:2 soil to water ratio using a glass electrode (H19017 microprocessor) pH meter as described by Jaiswal (2003). EC was measured using Jenway 4320 EC meter, organic carbon content of the soil was determined by wet oxidation method and total nitrogen was determined by the macro kjeldahl digestion, distillation and titration procedure as described by Jaiswal (2003). The available P was determined using Bray 1 method as described by Bray and Kurtz (1945). Exchangeable bases were extracted with one normal $(1 \mathrm{~N})$ ammonium acetate. Potassium and Sodium were determined using flame photometer, while Calcium and Magnesium was determined by titration with 0.01N EDTA (ethylene di-amine tetra-acetic acid), the soil was extracted with unbuffered $1.0 \mathrm{M} \mathrm{KCl}$, and the sum of $\mathrm{Al}^{3+}$ and $\mathrm{H}^{+}$was titrated with $0.1 \mathrm{M}$ $\mathrm{NaOH}$ in the presence of phenolphthalein indicator to a permanent pink color (Jaiswal, 2003). The same sample was titrated with $0.05 \mathrm{~N} \mathrm{Hcl}$ to a colorless end point after adding a drop of $0.05 \mathrm{~N} \mathrm{Hcl}$ and NaF respectively to determine the amount of $\mathrm{Al}^{3+}$ alone. The difference between total and exchangeable $\mathrm{Al}^{3+}$ alone and $\mathrm{H}^{+}+\mathrm{Al}^{3+}$ gives value for $\mathrm{H}^{+}$. However, the amount of exchangeable $\mathrm{H}$ alone is the difference between total exchangeable acidity and that of Al alone (Jaiswal, 2003). ECEC was determined by summation method (IITA, 1984). The PBS was calculated as a percentage of the ECEC (Jaiswal, 2003). Oxalate extractable iron was determined as described by Parfit and Childs (1988), CBD extractable and pyrophosphate extractable iron was determined as described by Blakemore et al. (1987).

Soil samples collected from the experimental pots after every 30 days were analyzed for $\mathrm{pH}$, and different fractions of phosphorus. The soil $\mathrm{pH}$ was determined as described by Jaiswal (2003). Total P and Organic $\mathrm{P}$ were determined using ignition method, where $2 \mathrm{~g}$ of air dried soil sample was ignited at $550^{\circ} \mathrm{c}$ for 1 
hour in a muffle furnace, and another $2 \mathrm{~g}$ was unignited and were then treated with $30 \mathrm{ml}$ of $0.1 \mathrm{M} \mathrm{H}_{2} \mathrm{SO}_{4}$ for at least 16 hours. Phosphorus in the filtrates were determined using the calorimeter method while the different fractions of inorganic $\mathrm{P}$ (Ca-P, reductant soluble $\mathrm{P}, \mathrm{Fe}-\mathrm{P}, \mathrm{Al}-\mathrm{P}$, and easily soluble or saloid $\mathrm{P}$ ) were fractionated (Williams et al., 1967). Ammonium chloride $\left(\mathrm{NH}_{4} \mathrm{Cl}\right)$ was used first to remove soluble and loosely bound $\mathrm{P}$, followed by separating Al-P from Fe-P with $\left(\mathrm{NH}_{4} \mathrm{~F}\right)$, then removing $\mathrm{Fe}-\mathrm{P}$ with $\mathrm{NaOH}$. The reductant-soluble $\mathrm{P}$ was removed with $\mathrm{CDB}$ (sodium citrate-sodium dithionite-sodium bicarbonate) extraction, while Ca-P was extracted with sulfuric acid $\left(\mathrm{H}_{2} \mathrm{SO}_{4}\right)$.

\section{Manure Incorporation}

The ground manures were applied at the recommended rate of $60 \mathrm{Kg} \mathrm{P} / \mathrm{ha}$ of single super phosphate (SSP)(Sanusan et al., 2009) by incorporating the manures into the soil to hasten the decomposition of the organic materials. The total amount of the organic material applied was estimated based on the result of the soil routine analyses conducted.

\section{Experimental Layout}

Experiment was laid out in a completely randomized design (CRD) replicated three (3) times with the following treatments:

i. $\quad$ Organic manure source (three treatments): control, cow dung and poultry droppings

ii. Organic manure level (three treatments): 5 ton ha ${ }^{-1}, 10$ ton ha ${ }^{-1}$ and 15 ton ha ${ }^{-1}$.

iii. Incubation time (three treatments): 30, 60 and 90 days after incubation (DAS).

\section{Data Analysis}

The data collected were analyzed using Statistical analysis software (SAS) (Arthur, 2013) and the means were separated using least significant difference (LSD) (Gomez and Gomez, 1984).

\section{Results And Discussion}

The soil of the study area is black in color and clay loam in texture. Tya Tahye (2011) reported same texture and color while studying the soils of the area. Soil pH in water was slightly acidic. Similar results were reported by Usman (2005). Ammonium and nitrate nitrogen content were low as reported by Marx et al. (1996). Available P content was moderate. Usman (2005) and Marx et al. (1996) also reported moderate available P content. Low organic matter content was also recorded. This corroborates with the findings of Marx et al. (1996) and Usman (2005). This may be attributed to the rapid decomposition rate of organic materials due high temperature and continuous cultivation (Jones and Wild, 1975; Singh, 1997).

Analysis of the organic materials revealed that highest moisture was recorded in cow dung while organic carbon content was highest in cow dung compared to poultry droppings. Highest N, P, and K values were recorded in poultry droppings. Similar results were obtained by Vanlauwe et al. (2001) while characterizing organic materials. The least $\mathrm{N}$ content was in cow dung. However, $\mathrm{N}$ content in poultry droppings was not as high as that recorded by Vanlauwe et al. (2001). This may be due to the release of ammoniumnitrogen and subsequent loss during handling (Brady and Weil, 2008).

Application of the organic materials generally increased soil $\mathrm{pH}$ at the initial stage of the experiment with poultry droppings application recording the highest $\mathrm{pH}$ value. The increased soil $\mathrm{pH}$ recorded by poultry droppings application at the initial stage of submergence (30 DAS) may primarily be attributed to the high $\mathrm{pH}$ of poultry droppings (8.2) at the time of application. Narambuye and Haynes (2006) reported that, during the initial decomposition of manures, prior to their collection, some formation of phenolic, humic-like material may usually occur. These organic anions consume protons from the soil thus, raising the equilibrium $\mathrm{pH}$. This increased $\mathrm{pH}$ may also be explained by proton $\left(\mathrm{H}^{+}\right)$exchange between the soil and the added organic materials (Tang et al., 1999). Another mechanism that was proposed to explained the increased in soil $\mathrm{pH}$ by such organic materials as poultry droppings is the specific adsorption of humic materials and/or organic acids onto the hydrous surfaces of $\mathrm{Al}$ and $\mathrm{Fe}$ oxides by ligands exchange with corresponding release of $\mathrm{OH}^{-}$( $\mathrm{Hue} e t$ al., 1986). The subsequent decrease in soil $\mathrm{pH}$ with increasing time of submergence was also observed by Opala et al. (2012). This decrease of soil $\mathrm{pH}$ with time may be due to the nitrification of nitrifiable $\mathrm{N}$, which is an acidifying process (Paul et al., 2001).

The contribution of total $\mathrm{P}$ content in the organic materials was apparent especially at the initial stage of submergence. Total $\mathrm{P}$ concentration increased with the application of organic materials at the initial stage of submergence and then began to decrease with increasing time of submergence, with poultry droppings treated soil having the highest total $\mathrm{P}$ concentration. Also an increase in total $\mathrm{P}$ concentration was observed with increasing level of organic materials application. The higher total $\mathrm{P}$ concentration observed in the poultry droppings application may be linked to the high $\mathrm{P}$ content of the applied organic material $(4.25 \%)$. Hesse (2002) stressed the validity of increased total $\mathrm{P}$ concentration when the soil $\mathrm{pH}$ exceeds 5.5. This promotes $\mathrm{P}$ 
mineralization. Midwest plan (2000) reported an average $\mathrm{P}$ content $\left(\mathrm{kgmt}^{-1}\right)$ of solid broiler poultry droppings of $9.5 \mathrm{~kg} \mathrm{mt}^{-1}$ compared to $0.7 \mathrm{kgmt}^{-1}$ of solid beef Cow dung and $0.5 \mathrm{kgmt}^{-1}$ of solid dairy cow dung. The increase in total $\mathrm{P}$ concentration with the addition of organic materials concurred with the findings of Fadly (2005), who attributed the increased total $\mathrm{P}$ concentration to the addition of organic matter and the possibility of mineralization and solubilization of occluded $\mathrm{P}$ and stabilized source of $\mathrm{P}$ in the existing soil organic matter. In addition, Garg and Bahla (2008) reported that, Poultry manure supplies phosphorus more readily to plants than other organic manure sources. The decrease in the concentration of Total $\mathrm{P}$ with time may be attributed to $\mathrm{P}$ resorption (Halvin et al., 2003).

The application of organic materials had a synergistic effect with organic P concentration. As the level of organic materials increased, an increased organic $\mathrm{P}$ concentration was observed. Also, organic $\mathrm{P}$ concentration increased with increasing time of submergence. The increase in organic $\mathrm{P}$ with the application of organic materials may be due to the high total $\mathrm{P}$ content of the organic materials added. According to Turner and Leytem (2004), Manure contains large amounts of organic P, such as phospholipids and nucleic acids which when added to soil increase the organic and total P content respectively. Harrison (1987) also reported that, organic P generally accounts for 30 to $65 \%$ of the total $\mathrm{P}$ in soils. The application of organic materials may also complex $\mathrm{Al}$ and $\mathrm{Fe}$ in either ionic form or as oxides hence preventing $\mathrm{P}$ from becoming permanently unavailable, raising the organic $\mathrm{P}$ concentration and consequently releasing the phosphates gradually into the soil solution thus increasing the organic P concentration as the time of submergence increases (90 DAS).

Addition of $\mathrm{P}$ from organic materials generally resulted in increased available P. it was observed that increase in both time of submergence and level of organic materials resulted in a corresponding increase in available $\mathrm{P}$. The increase in the concentration of available $\mathrm{P}$ as a result of the application of organic materials may be due to the effective chelating process of $\mathrm{Al}$ and $\mathrm{Fe}$ in soil by organic matter functional groups (AlvarezFernanez et al., 1997; Bhattacharyya et al., 2005) suppressing precipitation of $\mathrm{Al}$ and Fe phosphate, or just mineralization of organic P from the addition of organic materials (Haynes and Mokolobate, 2001; Tiessen et al., 1998). The increase in available $\mathrm{P}$ with time of submergence contrast with the findings Sharply (1983) who reported a decline in available $\mathrm{P}$ with time which was attributed to $\mathrm{P}$ sorption by the soil. However, this result is in line with the reports of Opala (2012); Laboski and Lamb (2003); Spychaj-Fabisiak et al. (2005). They explained that the increase in $\mathrm{P}$ availability with time may be due to microbially mediated mineralization of soil organic $\mathrm{P}$ at a faster rate than that of $\mathrm{P}$ sorption by the soil of low to moderate $\mathrm{P}$.

Saloid P concentration was dependent on the source of organic materials. An increase in Saloid P concentration with the application of poultry droppings was observed whereas, its concentration declined with cow dung application. However, as the time of submergence increases, Saloid P concentration decreases. This rise in Saloid $\mathrm{P}$ concentration with the addition of Poultry may due to its ability to supply phosphorus more readily to plants than other organic manure sources (Garg and Bahla, 2008). The decline in Saloid P concentration with time can be attributed mainly to uptake by plant roots. Willet (1986) attributed the decrease in readily available $\mathrm{P}$ to plants to the flooding and dry conditions which increased the activity of ferric hydrous oxides in sorbing $\mathrm{P}$ that resulted in the immobilization of added $\mathrm{P}$ after draining the rice soils. Mandai and Khan (1975) obtained similar result.

A decline in the concentration of Aluminium bound $\mathrm{P}$ with time of submergence was observed. Nevertheless; Al-P concentration increases with the application of organic materials. The antagonism observed between Al-P and time of submergence may be due to the absence/ reduction of $\mathrm{P}$ sorption by Al there by resulting in a decline in Al-P concentration with Time of submergence. It may also be linked to its transformation to Fe-P or Ca; Vanlauwe et al. (2001) obtained similar result and stated that; with the passage of time, some portion of the Al-P might be converted to Fe-P and $\mathrm{Ca}$ depending upon the soil characteristics. The synergism observed by Al-P and organic materials was in contrast with the findings of many authors (AlvarezFernandez et al., 1997; Bhattacharyya et al., 2005; Anthony et al., 2008) who reported a decrease in Al-P concentration when organic materials were applied. They attributed the decrease to the effective chelating process of $\mathrm{Al}$ in soil by organic matter functional groups suppressing precipitation of $\mathrm{Al}$. However, the rise in Al-P concentration may be connected mainly to the effect of soil $\mathrm{pH}$ rather than that of added organic materials. Abolfazli et al. (2012) obtained similar result and reported that Fe-P and Al-P predominate in acids. Also, it was reported that Fe-P and Al-P constituted $55 \%$ of total $\mathrm{P}$ in acidic soil (Vanluawe et al., 2001).

Time of submergence had a significant influence on the concentration of Fe-P. A decline in Fe-P concentration with time of submergence was observed. This antagonism is in line with the findings of Ponnamperuma (1985) who reported that submergence resulted in the reduction of Fe-P as a result of hydrolysis and dissolution of Fe-P on submerging the soil. Furthermore, this may be attributed to the continuous depletion of easily soluble (Saloid) $\mathrm{P}$ with time thereby presenting a favourable environment for more Fe-P to be released into the soil solution resulting in a decline in Fe-P concentration.

The levels of organic materials had no significant influence on the concentration of RS-P, however, maximum and minimum concentration were recorded at 15 ton $\mathrm{ha}^{-1}$ and 5 ton $\mathrm{ha}^{-1}$ respectively. There was a 
decline in RS-P concentration with time of submergence nevertheless; application of organic materials increased the concentration of RS-P. The increase in RS-P may be associated with the increase in available $\mathrm{P}$ when organic materials were applied. Shariatmadari et al. (2007) reported that RS-P concentration was significantly correlated with soil available P. Also, it may be possible that organo-metal complexes mainly, Al, Fe and $\mathrm{Mn}$, remove $\mathrm{P}$ from solution and reduced the amount of $\mathrm{P}$ loss via runoff and leaching by formation of a cationic bridge between the organic $\mathrm{C}$ and $\mathrm{P}$ (Leytem and Westermann, 2003). The reduction of free hydrous Fe oxides during flooding, and the liberation of sorbed and co precipitated $\mathrm{P}$ increased the levels of extractable $\mathrm{P}$ in flooded acidic soil (Willet, 1989). An increase in $\mathrm{pH}$ in fact, favors $\mathrm{P}$ desorption from clay, iron and aluminum oxides. Such pH changes were however, found to favor desorption of freshly applied P only (Willet 1989).

Calcium bound $\mathrm{P}(\mathrm{Ca}-\mathrm{P})$ concentration decreases with time of submergence. This decline in Ca-P concentration with time of submergence may not be unconnected to the decline in soil $\mathrm{pH}$ with time. However, an increase in Ca-P concentration with the addition of organic materials was observed. The synergy between Ca$\mathrm{P}$ and organic materials contradicts the findings of Halajnia et al. (2009) who reported that organo-metal complexes were involved in the inhibition of Ca-P precipitation. However, the rise in Ca-P concentration with poultry droppings application may be associated with the rise in soil $\mathrm{pH}$ when poultry droppings were applied. This concurred with the findings of Shen et al. (2004) and Abolfazli et al. (2012). They reported that, the dominant total inorganic $\mathrm{P}$ fraction in the calcareous soil at the long-term field trial was Ca-P (69-71\% of total inorganic P). It may also be attributed to the high $\mathrm{pH}$ value of the applied poultry droppings (8.2) which may indicate high calcium content of the organic material. Robinson and Sharpley (1996) obtained similar result and reported that, high $\mathrm{Ca}$ contents of some animal manure could enhance $\mathrm{PO}_{4}$ sorption capacity of soils by the formation of Ca-P precipitates and complexes. In general, on calcareous soils, Ca-P are the predominate pool of soil $\mathrm{P}$ and their solubility is not directly influenced by redox reactions (Sah and Mikkelsen, 1986).

Conclusion

Level, type of organic materials and time of submergence significantly contributed to the differences in $\mathrm{P}$ forms under submerged condition. Fixation of $\mathrm{P}$ by $\mathrm{Fe}, \mathrm{Al}$ and $\mathrm{Ca}$ were greatly reduced on submerging the soils.

Table 1: Some Physical and Chemical Properties of Soil $(0-20 \mathrm{~cm})$ of the Experimental Site

\begin{tabular}{ll}
\hline Parameters & $0-20 \mathrm{~cm}$ \\
\hline $\mathrm{pH}(1: 2$ soil to water) & 6.20 \\
$\mathrm{Ec}(\mathrm{dS} / \mathrm{m})$ & 0.16 \\
$\mathrm{OC}(\mathrm{g} / \mathrm{kg})$ & 5.7 \\
$\mathrm{OM}(\mathrm{g} / \mathrm{kg})$ & 9.8 \\
$\mathrm{TN}(\mathrm{g} / \mathrm{kg})$ & $7.0 \times 10^{-2}$ \\
$\mathrm{AV}-\mathrm{N} \mathrm{NH} 4(\mathrm{~g} / \mathrm{kg})$ & $9.8 \times 10^{-3}$ \\
$\mathrm{AVN} \mathrm{NO3}(\mathrm{g} / \mathrm{kg})$ & $8.4 \times 10^{-3}$ \\
$\mathrm{AV} \mathrm{P}(\mathrm{mg} / \mathrm{kg})$ & 9.09 \\
$\mathrm{H}+\mathrm{AL}(\mathrm{cmol}(+) / \mathrm{kg})$ & 2.20 \\
$\mathrm{H}(\mathrm{cmol}(+) / \mathrm{kg})$ & 0.72 \\
$\mathrm{AL} \mathrm{cmol}(+) / \mathrm{kg})$ & 1.48 \\
$\mathrm{Ca}(\mathrm{cmol}(+) / \mathrm{kg})$ & 3.80 \\
$\mathrm{Mg}(\mathrm{cmol}(+) / \mathrm{kg})$ & 0.84 \\
$\mathrm{~K}(\mathrm{cmol}(+) / \mathrm{kg})$ & 0.27 \\
$\mathrm{Na}(\mathrm{cmol}(+) / \mathrm{kg})$ & 0.21 \\
$\mathrm{ECEC}(\mathrm{cmol}(+) / \mathrm{kg})$ & 7.32 \\
$\mathrm{PBS}(\%)$ & 69.95 \\
$\mathrm{Bulk} \mathrm{density}(\mathrm{g} / \mathrm{cm} 3)$ & 1.42 \\
Sand $(\%)$ & 40.80 \\
Silt $(\%)$ & 24.00 \\
Clay $(\%)$ & 35.20 \\
Texture & $\mathrm{CL}$ \\
Color & $7.5 \mathrm{YR} 2.5 / 1$ \\
\hline
\end{tabular}


Table 2: Characterization of Organic Materials

\begin{tabular}{lllllll}
\hline & Moist $(\%)$ & $\mathrm{N}(\mathrm{g} / \mathrm{kg})$ & $\mathrm{P}(\mathrm{mg} / \mathrm{kg})$ & $\% \mathrm{~K}$ & $\mathrm{OC}(\mathrm{g} / \mathrm{kg})$ & $\mathrm{pH}$ \\
\hline Poultry droppings & 28.45 & 21.6 & 4250 & 3.01 & 220.1 & 8.2 \\
Cow dung & 34.63 & 19.2 & 800 & 2.75 & 318.2 & 7.8 \\
\hline
\end{tabular}

Table 3: Effects of Organic Materials on Soil pH and Some Phosphorus (mg/kg) Fractions in First

Trial

\begin{tabular}{|c|c|c|c|c|c|c|c|c|c|}
\hline Trts & $\mathrm{pH}$ & Tot-P & Org.P & Av.P & Saloid P & Al-P & Fe-P & RS-P & $\mathrm{Ca}-\mathrm{P}$ \\
\hline \multicolumn{10}{|l|}{ Level } \\
\hline 5 ton $\mathrm{ha}^{-1}$ & $7.09^{\mathrm{a}}$ & $71.53^{b}$ & $20.92^{\mathrm{b}}$ & $5.47^{\mathrm{b}}$ & $7.10^{\mathrm{b}}$ & $19.46^{\mathrm{a}}$ & $10.45^{\mathrm{a}}$ & $7.06^{\mathrm{a}}$ & $6.40^{\mathrm{a}}$ \\
\hline 10 ton $\mathrm{ha}^{-1}$ & $7.01^{\mathrm{a}}$ & $81.65^{\mathrm{b}}$ & $22.78^{\mathrm{b}}$ & $6.28^{\mathrm{b}}$ & $13.46^{\mathrm{a}}$ & $21.28 \mathrm{a}$ & $10.60^{\mathrm{a}}$ & $6.94^{\mathrm{a}}$ & $7.39^{\mathrm{a}}$ \\
\hline 15 ton $^{-1}$ & $6.92^{\mathrm{a}}$ & $107.66^{\mathrm{a}}$ & $35.97^{\mathrm{a}}$ & $7.45^{\mathrm{a}}$ & $13.10^{\mathrm{a}}$ & $18.06^{\mathrm{a}}$ & $9.15^{\mathrm{a}}$ & $8.09^{\mathrm{a}}$ & $7.89^{\mathrm{a}}$ \\
\hline Mean & 7.01 & 86.95 & 26.56 & 6.40 & 11.22 & 19.60 & 10.07 & 7.36 & 7.22 \\
\hline LSD & 0.227 & 22.06 & 6.608 & 0.941 & 3.530 & 5.824 & 1.98 & 1.97 & 2.13 \\
\hline \multicolumn{10}{|l|}{$\underline{\text { Time }}$} \\
\hline $30 \mathrm{DAS}$ & $7.20^{\mathrm{a}}$ & $75.09^{b}$ & $17.23^{\mathrm{b}}$ & $5.29^{\mathrm{b}}$ & $17.88^{\mathrm{a}}$ & $36.25^{\mathrm{a}}$ & $7.43^{b}$ & $9.17^{\mathrm{a}}$ & $9.22^{\mathrm{a}}$ \\
\hline 60 DAS & $7.01^{\mathrm{ab}}$ & $106.89^{\mathrm{a}}$ & $32.69^{\mathrm{a}}$ & $5.79^{\mathrm{b}}$ & $11.67^{\mathrm{b}}$ & $15.12^{\mathrm{b}}$ & $14.81^{\mathrm{a}}$ & $7.95^{\mathrm{a}}$ & $10.23^{\mathrm{a}}$ \\
\hline 90 DAS & $6.81^{\mathrm{b}}$ & $78.87^{\mathrm{b}}$ & $29.75^{\mathrm{a}}$ & $8.11^{\mathrm{a}}$ & $4.10^{\mathrm{c}}$ & $7.44^{\mathrm{c}}$ & $7.97^{\mathrm{b}}$ & $4.87^{\mathrm{b}}$ & $2.20^{\mathrm{b}}$ \\
\hline Mean & 7.01 & 86.95 & 26.56 & 6.40 & 11.22 & 19.60 & 10.07 & 7.36 & 7.22 \\
\hline LSD & 0.227 & 22.06 & 6.608 & 0.941 & 3.530 & 5.824 & 1.98 & 1.97 & 2.13 \\
\hline \multicolumn{10}{|l|}{ Type } \\
\hline Control & $6.77^{\mathrm{b}}$ & $55.00^{\mathrm{b}}$ & $12.32^{\mathrm{c}}$ & $5.59^{\mathrm{b}}$ & $5.98^{\mathrm{b}}$ & $15.80^{\mathrm{b}}$ & $11.04^{\mathrm{a}}$ & $5.34^{\mathrm{b}}$ & $5.70^{\mathrm{b}}$ \\
\hline cow dung & $6.91^{\mathrm{b}}$ & $75.93^{\mathrm{b}}$ & $28.17^{\mathrm{b}}$ & $6.12^{\mathrm{b}}$ & $4.63^{b}$ & $18.70^{\mathrm{ab}}$ & $9.52^{\mathrm{a}}$ & $9.54^{\mathrm{a}}$ & $6.65^{b}$ \\
\hline Poultry D. & $7.34^{\mathrm{a}}$ & $129.90^{\mathrm{a}}$ & $39.17^{\mathrm{a}}$ & $7.48^{\mathrm{a}}$ & $23.04^{\mathrm{a}}$ & $24.31^{\mathrm{a}}$ & $9.64^{\mathrm{a}}$ & $7.20^{\mathrm{b}}$ & $9.31^{\mathrm{a}}$ \\
\hline Mean & 7.01 & 86.95 & 25.56 & 6.40 & 11.22 & 19.60 & 10.07 & 7.36 & 7.22 \\
\hline LSD & 0.227 & 22.06 & 6.608 & 0.941 & 3.530 & 5.824 & 1.98 & 1.97 & 2.13 \\
\hline
\end{tabular}

DAS = Days after emergence, Poultry D. = poultry droppings, Tot. $\mathrm{P}=$ total phosphorus, Org. $\mathrm{P}=$ organic Phosphorus, AV = available Phosphorus, Saloid P = Saloid or easily soluble phosphorus, Al-P = aluminium bound phosphorus, Fe-P = iron bound phosphorus, RS-P = reductant soluble phosphorus, $\mathrm{Ca}-\mathrm{P}=\mathrm{Calcium}$ bound phosphorus

Table 4: Effects of Organic Materials on Soil pH and Some Phosphorus (mg/kg) Fractions in Second Trial

\begin{tabular}{|c|c|c|c|c|c|c|c|c|c|}
\hline \multicolumn{2}{|c|}{$\mathrm{pH}$} & \multirow[t]{2}{*}{ Tot-P } & \multirow[t]{2}{*}{ Org.P } & \multirow[t]{2}{*}{ Av.P } & \multirow[t]{2}{*}{ Saloid P } & \multirow[t]{2}{*}{ Al-P } & \multirow[t]{2}{*}{ Fe-P } & \multirow[t]{2}{*}{ RS-P } & \multirow[t]{2}{*}{ Ca-P } \\
\hline$\underline{\text { Level }}$ & & & & & & & & & \\
\hline 5 ton $\mathrm{ha}^{-1}$ & $6.81^{\mathrm{b}}$ & $79.50^{\mathrm{b}}$ & $18.33^{\mathrm{c}}$ & $15.88^{\mathrm{c}}$ & $11.03^{\mathrm{b}}$ & $16.28^{\mathrm{a}}$ & $11.46^{\mathrm{a}}$ & $6.45^{\mathrm{a}}$ & $3.61^{\mathrm{a}}$ \\
\hline 10 ton $\mathrm{ha}^{-1}$ & $6.93^{\mathrm{ab}}$ & $86.62^{\mathrm{b}}$ & $21.42^{\mathrm{b}}$ & $17.51^{\mathrm{b}}$ & $12.95^{\mathrm{b}}$ & $15.96^{\mathrm{a}}$ & $12.93^{\mathrm{a}}$ & $5.82^{\mathrm{a}}$ & $4.09^{\mathrm{a}}$ \\
\hline 15 ton $\mathrm{ha}^{-1}$ & $6.97^{\mathrm{a}}$ & $111.48^{\mathrm{a}}$ & $37.91^{\mathrm{a}}$ & $20.72^{\mathrm{a}}$ & $14.94^{\mathrm{a}}$ & $13.33^{\mathrm{b}}$ & $12.65^{\mathrm{a}}$ & $6.58^{\mathrm{a}}$ & $3.93^{\mathrm{a}}$ \\
\hline Mean & 6.91 & 92.53 & 25.89 & 18.03 & 12.97 & 15.15 & 12.35 & 6.28 & 3.88 \\
\hline LSD & 0.142 & 12.52 & 1.81 & 1.43 & 1.96 & 2.17 & 2.04 & 0.99 & 1.08 \\
\hline \multicolumn{10}{|l|}{$\underline{\text { Time }}$} \\
\hline $30 \mathrm{DAS}$ & $7.09^{\mathrm{a}}$ & $119.82^{\mathrm{a}}$ & $22.44^{\mathrm{b}}$ & $21.82^{\mathrm{a}}$ & $14.28^{\mathrm{b}}$ & $15.99^{\mathrm{b}}$ & $18.19^{\mathrm{a}}$ & $9.48^{\mathrm{a}}$ & $4.95^{\mathrm{a}}$ \\
\hline 60 DAS & $6.80^{\mathrm{b}}$ & $81.02^{\mathrm{b}}$ & $23.47^{\mathrm{b}}$ & $11.83^{\mathrm{b}}$ & $19.83^{\mathrm{a}}$ & $22.17^{\mathrm{a}}$ & $10.82^{\mathrm{b}}$ & $4.54^{\mathrm{b}}$ & $3.43^{b}$ \\
\hline 90 DAS & $6.83^{\mathrm{b}}$ & $76.77^{\mathrm{b}}$ & $31.76^{\mathrm{a}}$ & $20.45^{\mathrm{a}}$ & $4.81^{\mathrm{c}}$ & $7.30^{c}$ & $8.02^{c}$ & $4.83^{\mathrm{b}}$ & $3.25^{\mathrm{b}}$ \\
\hline Mean & 6.91 & 92.53 & 25.89 & 18.03 & 12.97 & 15.15 & 12.35 & 6.28 & 3.88 \\
\hline LSD & 0.142 & 12.52 & 1.81 & 1.43 & 1.96 & 2.17 & 2.04 & 0.99 & 1.08 \\
\hline
\end{tabular}


Type

\begin{tabular}{llllllllll} 
Control & $6.56^{\mathrm{c}}$ & $71.42^{\mathrm{c}}$ & $13.49^{\mathrm{c}}$ & $15.92^{\mathrm{c}}$ & $13.73^{\mathrm{b}}$ & $14.77^{\mathrm{b}}$ & $15.58^{\mathrm{a}}$ & $8.50^{\mathrm{a}}$ & $3.98^{\mathrm{ab}}$ \\
cow dung & $6.86^{\mathrm{b}}$ & $88.17^{\mathrm{b}}$ & $28.06^{\mathrm{b}}$ & $17.87^{\mathrm{b}}$ & $3.64^{\mathrm{c}}$ & $13.20^{\mathrm{b}}$ & $10.87^{\mathrm{b}}$ & $6.13^{\mathrm{b}}$ & $3.24^{\mathrm{b}}$ \\
Poultry D. & $7.30^{\mathrm{a}}$ & $118.02^{\mathrm{a}}$ & $36.11^{\mathrm{a}}$ & $20.31^{\mathrm{a}}$ & $21.56^{\mathrm{a}}$ & $17.48^{\mathrm{a}}$ & $10.53^{\mathrm{b}}$ & $4.21^{\mathrm{c}}$ & $4.41^{\mathrm{a}}$ \\
Mean & 6.91 & 92.53 & 25.89 & 18.03 & 12.97 & 15.15 & 12.35 & 6.28 & 3.88 \\
LSD & 0.142 & 12.52 & 1.81 & 1.43 & 1.96 & 2.17 & 2.04 & 0.99 & 1.08 \\
\hline
\end{tabular}

DAS = Days after emergence, Poultry D. = poultry droppings, Tot. $\mathrm{P}=$ total phosphorus, Org. $\mathrm{P}=$ organic Phosphorus, AV = available Phosphorus, Saloid $\mathrm{P}=$ Saloid or easily soluble phosphorus, $\mathrm{Al}-\mathrm{P}=$ aluminium bound phosphorus, Fe-P = iron bound phosphorus, RS-P = reductant soluble phosphorus, Ca-P = Calcium bound phosphorus

\section{References}

[1]. Adebayo, A. A. (1999). Climate I: Sunshine, Temperature, Evaporation and Relative Humidity. In: Adamawa State in Maps. Adebayo A.A. and A. H. Tukur (Eds.) Paracletes Publishers and Department of Geography Federal University of Technology Yola, Nigeria. Pp. 3 - 5.

[2]. Abolfazli, F., A Forghani and M. Norouzi (2012). Effects of phosphorus and organic fertilizers on phosphorus fractions in submerged soil. Journal of soil science and plant nutrition, 12, (2) 349-362.

[3]. Al-varez, A., A. Garate, and J.J. Lucena (1997). Interaction of iron chelates with several soil materials and with a soil standard . Journal of plant nutrition, 20:559-572.

[4]. Anthony, K. O., Ezikiel, A.A. and Gabriel, O.O. (2008). Phosphorus dynamics in forest and savannah agro-ecological alfisols incubated with different phosphorus fertilizers. Journal of food, agriculture and environment, 6 (3 \& 4): 34-537.

[5]. Arthur, L. (2013). Handbook of SAS DATA Step Programming. CRC Press. pp. 149. ISBN 978-1-4665-5238-8.

[6]. Bar-Yosef, B. (2004). Phosphorus, dynamics. In : Benbi, D. K. and Nieder, R. (eds) Handbook of Processes and Modelling in the soil- Plant system. Viva Books Privali Ltd. New Delhi. 762pp.

[7]. Bhattacharyya, P., Chakrabarti, K., Charkraboty, A., and Nayak, D.C (2005).Effect of municipal solid waste compost on phosphorus content of rice straw and grain under submerged conditions. Archives of agronomy and soil science. 51, 4, 363-370.

[8]. Blackmore, L.C., Searle, P.L. and Daly, B.K. (1987). Methods for Chemical Analysis of Soils. New Zealand Soil Bureau Scientific Report 80.p. 103.

[9]. Brady, N. C., and Weil, R. R. (2008). The Nature and Properties of Soils (14 ${ }^{\mathrm{TH}}$ ed.). Prentice hall Inc. New Delhi. 980pp.

[10]. Bray, R.A and Kurtz, L.T. (1945). Determination of Total and Available Forms of Phosphorus In: Soil Science, 38. 617 - 628.

[11]. Fadly, H. Y. (2005). Soil Organic Matter Decomposition: Effects of Organic Matter Addition on Phosphorus Dynamics in Lateritic Soils.University of Western Australia.Pp. $20-98$.

[12]. Garg, S. and Bahla, G.S. (2008). Phosphorus Availability to Maize as Influenced by Organic Manures and Fertilizer P Associated Phosphatase Activity in soils. Bio resource Technology; 99:5773-5777.

[13]. Gomez, A. K. and Gomez, A. A. (1984). Statistical Procedure for Agricultural Research. John Wiley and Sons. pp 657.

[14]. Havlin, L.J; Beaton, J.D; Tisdale, S. L. and Nelson,W.L. 2003. Soil Fertility and Fertilizers: An Introduction to Nutrient Management. Sheel Print Opack, India. Pp449

[15]. Halajnia, A., Haghnia, G.H., Fotovat, A., Khorasani, R. (2009). Phosphorus fractions in calcareous soils amended with P fertilizer and cattle manure. Geoderma. 150, 209-213.

[16]. Harrison, A. F. (1987). Soil Organic Phosphorus—A Review of World Literature. CAB International, Wallingford, Oxon, UK, p. 257.

[17]. Haynes, R. J. and M. S. Mokolobate, (2001). Amelioration of Al toxicity and P deficiency in acid soils by additions of organic residues: a critical review of the phenomenon and the mechanisms involved. Nutrient Cycling in Agro ecosystems. 59, 1: 47-63.

[18]. Hesse, R.R. (2002). A Text Book of Soil Chemical Analysis. CBS. Publishers and Distributors, New Delhi India, Pp. $332-343$.

[19]. Hue, V. G. R. Craddock, and F. Adams, (1986). Effects of organic acids on aluminum toxicity in subsoil, Soil Science Society of America Journal. 25: 3291-3303.

[20]. IITA 1984. Soil and Plant Analyses: Study guide for agricultural laboratoty directions and technologist working in tropical regions (D. A. Tel and M. Hagarty edits). Pp 278.

[21]. Jaiswal, P. C. (2003). Soil, Plant and Water Analyses. Kalyani Publishers Ludhiana, New Delhi - Norda Hyderabab, India. Pp. 1 399.

[22]. Jones, M. J. and Wild, A. (1975). Soils of West African Savanna: the maintenance and improvement of their fertility.technical Agricultural Bureaux, Technical Comm. No.55 of the commonwealth Bureaux of soils.Harpenden. 246pp.

[23]. Kanwar, J. S. and Chopra, S. L. (1959). Practical Agricultural Chemistry. S. Chand and Co. Delhi - Jullundur - Lucknow India. Pp. 2 - 27.

[24]. Khalid, R. A., Patrick Jr.,W. H. and Delaune,E. D. (1977). Phosphorus Sorption Characteristics of Flooded Soils. Soil Science Society of America Proceeding, 41, $303-310$.

[25]. Leytem, A. B., Westermann, D.T. 2003. Phosphate sorption by pacific northwest calcareous soils. Journal of Soil Science, 168, 368-375.

[26]. Midwest Plan Service (2000). Manure Characteristics.Arnes, IA:IOWA State University Press. Pp. 56.

[27]. Mandai, L.N. and Khan, S. K. (1975): Influence of Soil Moisture Regime on Transformation of Inorganic Phosphorus in Rice Soils. Journal of Indian Society of Soil Science, 23. 31-37.

[28]. Marx, E. S., Hart, J. and Stevens, R.G. (1996). Soil test itarpretation guide. Oregon state university extension service. Corvallis, reprinted 1999. Pp 8.

[29]. Narambuye, F. X. and R. J. Haynes, (2006). "Effect of organic amendments on soil pH and Al solubility and use of laboratory indices to predict their liming effect," Soil Science. 17110, 10: 754-763.

[30]. Oelkers, E.H. and Valsami-Jones, E. (2008) .Phosphate Mineral Reactivity and Global Sustainability. Elements 4. 83-87.

[31]. Opala, P. A. J. R. Okalebo, and C. O. Othieno, (2012). Effects of Organic and Inorganic Materials on Soil Acidity and Phosphorus Availability in a Soil Incubation Study. ISRN Agronomy.10 pages, doi:10.5402/2012/597216.

[32]. Parfit, R.L. and Childs, C.W. (1988). Estimation of Forms of Fe and Al: A Reviewand Analysis of Contrasting Soils Using Dissolution and Moesbauer Methods. Australian Journal of Soil Resources, 26:121-144. 
[33]. Paul, K. I., A. S. Black, and M. K. Conyers, (2001). "Effect of plant residue return on the development of surface soil pH gradients," Biology and Fertility of Soils. 33, 1: 75-82.

[34]. Pierzynski, G. M., Mcdowell, R.W. and Sims, J. T. (2005). Chemistry, Cycling, and Potential Moment of Inorganic Phosphorus in Soils. In Sims JT, Sharpley AN, Eds, Phosphorus: Agriculture and the Environment. American Society of Agronomy, Crop Science Society of America, Soil Science Society of America, Inc., Madison, WI, Pp. 53-86.

[35]. Ponnamperuma, F. N. (1985). Wet Land Soil. Lrrl, Losbanos, Philippines. Pp.71-89.

[36]. Robinson, J.S., Sharpley, A.N. (1996). Reactions in soils of phosphorus released from poultry litter. Soil science society of America Journal, 60, 1583-1588.

[37]. Sah, R. N. and Mikkelsen, D. S. (1989). Phosphorus Behavior in Flooded - Drained Soil. I- Effects on Phosphorus Sorption. Soil science society of America Journal, 53, 1718 - 1722.

[38]. Sahrawat, K.L., Abekoe, M.K. and Diatta, S. (2001). Application of Inorganic Phosphorus Fertilizers. In: Sustaining Soil Fertility in West Africa. Special Publ. No. 58. Pp. 225-246.

[39]. Sanusan,S., Polthanee, A., Seripony, S., Audebert, A. and Mouret, J.C. (2009). Rates and timing of Phosphorus Fertilizer on Growth and Yield of Direct Seeded Rice in Rain Fed Conditions. Acta Agric. Scandinavica, Section B. Plant and Soil Science, 59. (6), 491499.

[40]. Schulte, E. E. (2004). Soil and Applied Iron. Cooperative Extension Publication,University of Wisconsin Extension. Pp. 1-2.

[41]. Shariatmadari, H., Shirvani, M., Dehghan, R.A. (2007). Availability of organic and inorganic phosphorus fractions to wheat in toposequences of calcareous soils. Commun. Soil Science and Plant Analysis. 38, 2601-2617.

[42]. Sharply A.N (1983). Effects of soil properties on the kinetics of phosphorus desorption. Soil science society of America Journal, 47:462-467.

[43]. Shen, J., Li, R., Zhanga, F., Fan, J., Tang, C., Rengel, Z. 2004. Crop yields, soil fertility and phosphorus fractions in response to long-term fertilization under the rice monoculture system on a calcareous soil. Field Crops Research. 86, 225-238.

[44]. Singh, L. (1997). Soil Fertility Management: The Key to High Crop Productivity. A.T.B.U. Inaugural Lecture Series No. 6. 36pp.

[45]. Spychaj-Fabisiak, E. J. Dlagoszand R Zamoski (2005). Effect of P dosage and incubation time on the process of retarding available $\mathrm{P}$ forms in a sandy soil. Polish journal of soil science. 38:23-30.

[46]. Tang, C. G. P. Sparling, C. D. A. McLay, and C. Raphael, (1999). Effect of short-term legume residue decomposition on soil acidity, Australian Journal of Soil Research, vol. 37, no. 3, pp. 561-573.

[47]. Tiessen, H. E. Cuevas and I.H.Salcedo (1998). Organic matter stability and nutrient availability under temperate and tropical conditions. Advances in geoecology 31:415-422.

[48]. Turner B.L. and Leytem, A.B. (2004) .Phosphorus Compounds in Sequential Extracts of Animal Manures: Chemical Speciation and a Novel Fractionation Procedure. Environ Science Technology, 38. 6101-6108.

[49]. Turner B.L., Richardson, A.E and Mullaney, E.J. (2007). Inositol Phosphates: Linking Agriculture and the Environment. CAB International, Wallingford, UK, p. 304.

[50]. Usman, B. H. (2005). The Soils of Adamawa State, North Eastern Nigeria. In: Agriculture in Adamawa State. Pracletes Publishers, Yola- Nigeria. Pp.62- 83.

[51]. Tya Tahye S. K. (2011). Assessment of Water Allocation Strategies on Adequacy and Equity of Water Distribution at Tertiary Level of Geriyo Irrigation Project. American-Eurasian Journal of Agriculture \& Environmental Science, 10 (3): 419-424, ISSN 1818-6769@ IDOSI Publications.

[52]. Vanlauwe, B., Wendt, J. and Diels, J. (2001). Combined Application of Organic Matter and Fertilizers. In: Tian et al., (ed.) Sustaining Soil Fertility in West Africa. Soil Science Society of America. Special Publication No. 58, Madison, W. I. p. 146.

[53]. Williams, J. D. H., Syer, J. K. and Walker, T. W. (1967). Fractionation of Soil Inorganic Phosphate by a Modification of Chang and Jackon's Procedure Lincoln College, Univ. of Canterbury, New Zealand .Pp. 736 - 739

[54]. Willet, I.R. ( 1989). Causes and prediction of changes in extractable phosphorous during flooding. Australia Journal of Soil Resources. 27, 45-54

[55]. Willet, I.R. (1986). Phosphorus Dynamics in Relation to Redox Processes in flooded soils. Trans. 13th International Congo Soil Science. (Hamburg) 6. 748-755. 